\title{
Endoglin Expression and The Level of TGF- $\beta$ are Increased in The Placental Tissue and Correlated with Low Fetal Weight in Malaria Infected Mice
}

Sujarot Dwi Sasmito ${ }^{1}$, Adilah Ulfiati ${ }^{1}$, Ardhian Wardana ${ }^{2}$, Fitriana Nugraheni ${ }^{2}$, Nur Fahma Pradiptasari ${ }^{2}$, Zakiyah Zulaifa ${ }^{2}$, Eviana Norahmawati ${ }^{3}$, Teguh Wahju Sardjono ${ }^{4}$, Loeki Enggar Fitri ${ }^{4}$

\author{
${ }^{1}$ Master Program in Biomedical Science, Faculty of Medicine, Universitas Brawijaya, 65145, Malang, Indonesia \\ ${ }^{2}$ Medical Study Program Faculty of Medicine, Universitas Brawijaya, 65145, Malang, Indonesia \\ ${ }^{3}$ Department of Pathology Anatomy, Faculty of Medicine, Universitas Brawijaya, 65145, Malang Indonesia \\ ${ }^{4}$ Department of Parasitology, Faculty of Medicine, Universitas Brawijaya, 65145, Malang, Indonesia
}

\begin{abstract}
Malaria infection during pregnancy can cause accumulation of infected red blood cells in placental intervillous space and induces placental tissue inflammation and hypoxia. This condition triggers endoglin expression and release of soluble endoglin that can interfere TGF- $\beta$ binding with the receptor. The aim of this study was to investigate the correlation between placental endoglin expression and TGF- $\beta$ level with low fetal weight (LFW) in malaria-infected mice. Nine pregnant mice infected with Plasmodium berghei on the day ninth post mating (malaria-infected group) and eight normal pregnant mice (non-infected group) were used in this study. The mice were sacrificed on the day 18th post mating, and all fetal body weights were measured by analytical scale. Enzyme Link Immunosorbent Assay (ELISA) was done to determine the level of placental TGF- $\beta$ while immunohistochemical staining was performed to examine endoglin expression in placental tissue. The mean of fetal body weights of malaria-infected group was significantly lower than non-infected group $(p=0,002)$, while the expression of placental endoglin in malaria- infected group was substantially higher than non-infected group $(p=0.003)$. The level of placental TGF- $\beta$ in malaria-infected group was also considerably higher than non-infected group, but the difference was not significant $(\mathrm{p}=0.064)$. Pearson correlation test showed that there were significant negative correlations between fetal body weights with the level of placental TGF- $\beta$ ( $p=0.017, r=-0.568$ ) and the expression of placental endoglin $(\mathrm{p}=0.002, r=-0.694)$. Malaria infection in pregnant mice will increase both TGF- $\beta$ and endoglin in placenta tissue and correlate with low fetal weight.
\end{abstract}

Keywords: endoglin, low fetal weight, malaria, Plasmodium berghei, TGF- $\beta$

\section{INTRODUCTION}

Malaria is one of the most common infectious diseases related to death in the world, especially in the tropical area. It is estimated affects between 350 to 500 million people annually and accounts for 1 to 3 million deaths per year. Twenty-five million pregnant women are currently at risk for malaria and accounts for over 10,000 maternal and 200,000 neonatal deaths per year. More than $90 \%$ of them are living in the Sub-Saharan Africa and may contribute to almost 25\% of maternal mortality $[1,2]$. Malaria in pregnancy also contributes to significant perinatal morbidity and mortality.

\footnotetext{
${ }^{*}$ Corresponding author:

Loeki Enggar Fitri

Department of Parasitology, Faculty of Medicine,

Universitas Brawijaya, 65145, Malang, Indonesia

E-mail: lukief@ub.acid
}

Infection is known to cause higher rates of miscarriage, intrauterine demise, premature delivery, low-birthweight neonates, and neonatal death [1].

The presence of Plasmodium in red blood cells (RBCs) will result in the attachment and accumulation or sequestration of infected RBCs at the placenta that is commonly known as placental malaria. It may cause placental inflammation, dysregulation of angiogenesis factor and damage to the placenta. All of those are the process responsible for decreasing nutrients and oxygen supply from the mother to fetus. This hypoxia conditions lead to inhibition of fetal growth and resulting in a low birth weight [3]. As a body response to compensate the lack of blood flow, a trigger of the angiogenesis process begins and involves pro and antiangiogenic factor. One of the pro-angiogenic factors that plays an important role is endoglin (Eng) [4]. 
Endoglin is upregulated during angiogenesis [5] and modulates TGF- $\beta$ signaling by interacting with TGF- $\beta$ receptors types I and II [6]. This function is rather different with the soluble form of endoglin (sEng) that binds directly to TGF- $\beta$ and limits TGF- $\beta$ bioavailability to its receptor. As a result, both of these conditions inhibit regulation of TGF- $\beta$ [7]. It has been known that increased circulating sEng levels are associated with $P$. falciparum infection in pregnancy and fetal growth restriction in primigravidae with placental malaria [8].

\section{MATERIALS AND METHODS Study Design}

The design of this study was an experimental study, conducted at the Laboratory of Parasitology and Laboratory of Biomedical, Faculty of Medicine, University of Brawijaya Malang. This study had been approved by the Ethical Committee of Health Research Faculty of Medicine University of Brawijaya (No. 104/EC/KEPK).

\section{Animal model}

Fifty female Balb/c mice aged 13-16 weeks that were obtained from the Animal Experimental Development Unit, University of Gadjah Mada, were used as an animal model.

Oestrus phase of the mice was synchronized by utilizing the Leeboot, Pheromone and Whitten effects. Afterward, the mice were simultaneously paired mated within one night [9] and were divided into two groups. On day ninth post mating (estimated to be the last first trimester of gestation), mice from one group were intraperitoneally infected with Plasmodium berghei and used as malaria-infected group and the other one was used for non-infected group.

\section{Infection of Plasmodium berghei ANKA strain to pregnant mice}

Pellet of erythrocytes infected with Plasmodium berghei ANKA strain obtained from the storage of liquid nitrogen tank $\left(-135^{\circ} \mathrm{C}\right.$ temperature $)$ at the Laboratory of Biomedical, Faculty of Medicine, University of Brawijaya was thawed and centrifuged at $2000 \mathrm{rpm}$ for 5 minutes and then washed twice in RPMI medium and diluted as needed to be injected intraperitoneally into three donor mice. Parasitemia level of donor mice was followed up and measured from the preparation of thin blood smears taken from the tail tip and stained with Giemsa. Number of parasites were counted per 1000 erythrocytes using a light microscope under 100x objective magnification. When the parasitemia reached above $15 \%$ (about 3-4 days after infection), meant that the mouse had been available to be used as donor of malaria infections. Infection of malaria into the malaria-infected group was done by injecting of 1x106/ml Plasmodium berghei ANKA strain (first passage) intraperitoneally on the day ninth post mating.

\section{Measuring degree of parasitemia}

The degrees of parasitemia of malaria-infected group were measured by examining slides of thin blood smear taken from mouse's tail tip and stained with Giemsa under light microscope with 100x objective magnification by two different and independent observers. Number of infected red blood cells (RBCs) were counted per 1000 RBCs.

\section{Isolation of placental tissue and fetus}

On the day 18th post mating, mice from the malaria-infected group and non-infected group were sacrificed under anesthesia of chloroform, and dissected by opening the abdominal wall to take the fetus and placental tissues. The fetus was weighted individually using analytical balance Mettler AE 50 while the placenta were separated individually and divided into two parts for measuring the level of placental TGF- $\beta$ and immunohistochemistry analysis.

\section{Isolation and Measuring level of placental TGF- $\beta$}

Placental TGF- $\beta$ were isolated from placenta tissue using modification of Qin [10] and Wang [11] method. Briefly placental tissues of each mouse were homogenized with $0.1 \mathrm{~m}$ Tris-buffered saline $(\mathrm{pH} 7.4)$ containing $0.5 \%$ Triton X-100 and one tablet of Complete Mini protease inhibitor (Roche Diagnostics, Indianapolis, IN). Afterward, they were centrifuged at $15,000 \mathrm{rpm}$ for 30 minutes and the supernatant was collected and protein concentration was measured. They then were kept at $-80^{\circ} \mathrm{C}$ until used for ELISA assay.

Levels of placental TGF- $\beta$ was measured using Quantikine ELISA Kit (Enzyme Immuno Assay) Inc. 1 plate from R\&D Systems, Catalog MB100B. Assay procedure was conducted as described according to kitprotocol.

\section{Immunohistochemistry of Placental Endoglin}

After deparaffinized, the slides were washed with Phosphate Buffer Saline (PBS) three times, dried and poured with $\mathrm{H} 2 \mathrm{O} 23 \%$ in methanol and then incubated for 15-20 minutes at room temperature. Antigen 
retrieval (AR) process used Heat-induced epitope retrieval (HIER) and was conducted by heating in a water bath at $95^{\circ} \mathrm{C}$ for 20 minutes in citrate buffer $\mathrm{pH}$ 0.6. Blocking protein was done by dropping triton-x 100 0.25\% in blocking buffer Bovine Serum Albumin (BSA) over 1 hour at room temperature and then washed using PBS. The next step, slides were dropped with primary antibody, Monoclonal Mouse AntiEndoglin antibody, from EMD Millipore (primary antibody: Fetal Bovine Serum (FBS) 5\% = 1:100) in blocking buffer BSA and incubated one night at temperature $4^{\circ} \mathrm{C}$. Next day, slides were washed using PBS and then incubated with secondary antibody antiIgG rabbit anti-mouse over 60 minutes at room temperature, then was followed by washing with PBS. The next step, slides were dropped using StreptavidinHorseradish Peroxidase (SA-HRP) in sterile PBS 1:500, incubated 40 minutes at room temperature, washed with PBS and washed again with sterile water three times. Chromogen Diaminobenzidine (DAB) (1:50) was added to all sample slides and incubated for 30 minutes at room temperature, and then washed with sterile PBS. Finally, slides were counterstained with Mayer hematoxylin, incubated 5-10 minutes at room temperature and washed with sterile tap water three times.

Observation and counting the number of endoglin expression in placental tissue was done by counting trophoblast cells that express brown color on the membrane of the cells. Counting was done by observing the number of positive cell in 1000 cell with 40x objective magnificient using light microscope.

\section{Data analysis}

Data analysis was performed using SPSS 16 with Kruskal-Wallis test, Independent T-test, and Pearson correlation test with $\alpha<0.05$.

\section{RESULTS AND DISCUSSION}

There were only 17 mice that got pregnant from 50 pairs of mated mice, nine pregnant mice as malariainfected group and 8 mice as non-infected group. It means that the pregnancy rate of these mice were only $34 \%$.

\section{Fetal body weight}

Statistical analysis was conducted using independent T-test after normality test (Kolmogorov-Smirnov; $\mathrm{p}$ infected group $=0.200, \mathrm{p}$ non-infected group $=0.200$ ). The fetal body weights of both groups are presented in figure 1A. The fetal body weight of the infected group was significantly lower than the non-infected group ( $p$ $=0.002$, independent T-test).

\section{The level of placental TGF- $\beta$}

Figure $1 \mathrm{~B}$ shows the level of placental TGF- $\beta$ of both groups (Kolmogorov-Smirnov; $\mathrm{p}$ infected group= 0.192, $\mathrm{p}$ non-infected group=0.062). Although the level

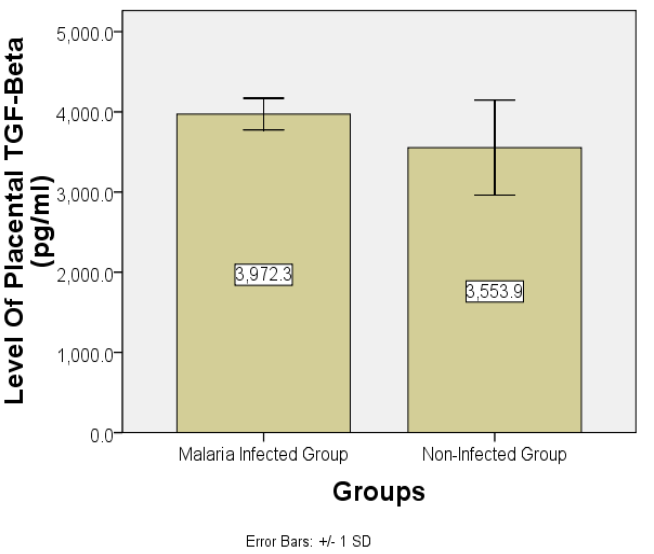

B

Figure 1. A. Comparison of the mean of fetal body weight of malaria-infected group and non-infected group ( $\mathrm{p}=0.002)$. Malariainfected group: pregnant mice with Plasmodium berghei infection; non-infected group: pregnant mice without Plasmodium berghei infection, B. Comparison of the average levels of placental TGF- $\beta$ of malaria-infected group and non-infected group ( $\mathrm{p}=0.064)$. Malaria-infected group: pregnant mice with Plasmodium berghei infection; non-infected group: pregnant mice without Plasmodium berghei infection. 


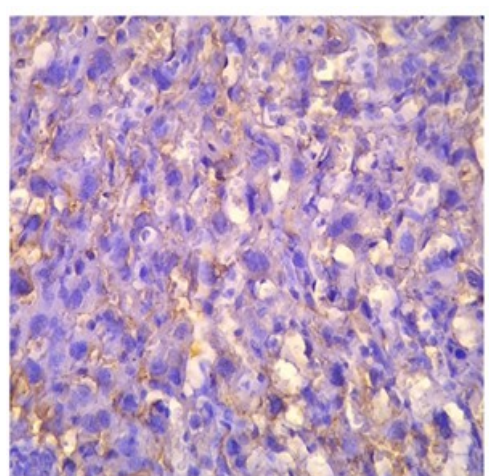

A

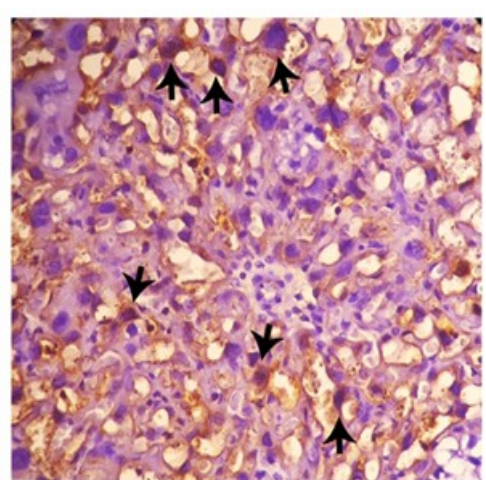

B

Figure 2. Expression id placntal endoglin in: A.. non-infected group, and B. malaria infected group. Arrows show trophoblast cells which express endoglin (brown color on membrane of the cell). Malaria infected group showed higher expression in placenta endoglin compare to non-infected group. Samples were observed under light microscope with 40x objective magnification.

of placental TGF- $\beta$ in the malaria-infected group seemed to be higher than non=infected group but there was no significant difference between them $(p=0.064$, independent T-test).

\section{The expression of placental endoglin}

Figure 2 shows the result of immunohistochemistry examination. The expression of placental endoglin of infected group was significantly higher than the mean of placental endoglin expression of non-infected group (Figure 3, Kolmogorov-Smirnov, $\mathrm{p}$ infected group= 0.200 , $p$ non-infected group $=0.200$; Independent $T$-test $\mathrm{p}=0.003)$.

\section{Correlation between variables}

Pearson correlation test was conducted to know the relationship between variables. Figure $4 \mathrm{~A}$ shows that there is a significant negative correlation between placental TGF- $\beta$ with fetal weight $(p=0.017 ; r=-0.568)$. Figure $4 \mathrm{~B}$ shows that there is also an important negative correlation between the expression of placental endoglin with fetal body weight $(\mathrm{p}=0.002 \mathrm{r}=-0.694)$.

\section{Placental malaria correlate with low fetal weight}

The fetal weights in non-infected group were significantly higher than malaria-infected group. This result is consistent with previous studies conducted in which the fetal body weight of mice with Plasmodium infection were lower as compared to fetal mice without infection $[12,13]$.

In placental malaria, the event of low fetal body weight can be mediated by infiltration of monocytes

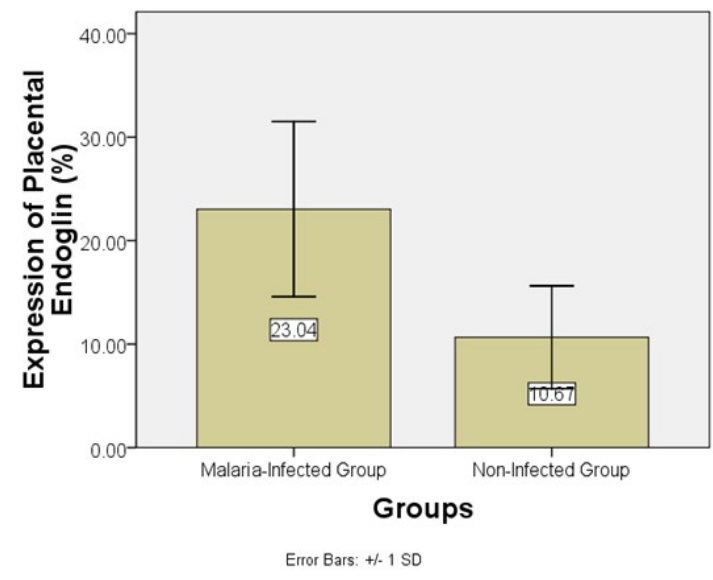

Figure 3. Comparison of the mean expression of placental endoglin of malaria-infected group and non-infected group ( $\mathrm{p}=0.003)$. Malaria-infected group: pregnant mice with Plasmodium berghei infection; non-infected group: pregnant mice without Plasmodium berghei infection. 


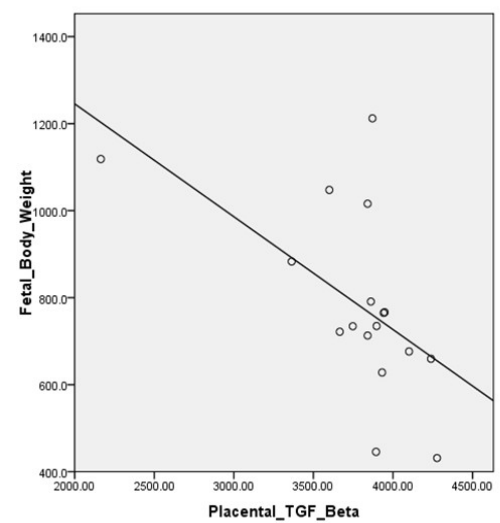

A
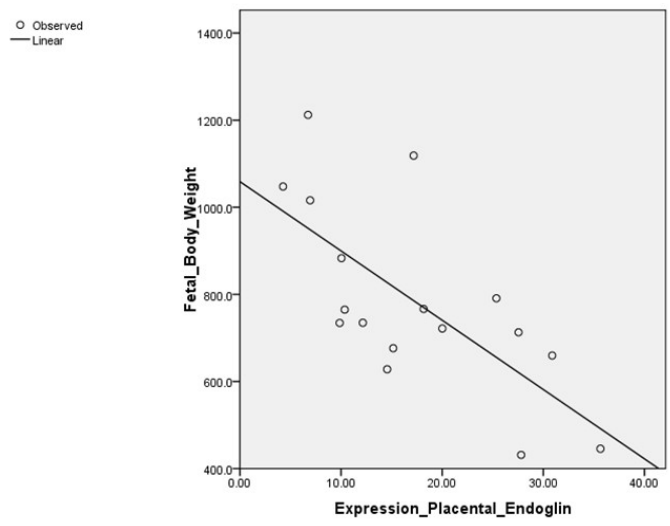

B

Figure 4. A. Correlation between placental TGF- $\beta$ and fetal body weight $(r=-0.568 ; p=0.017$, Pearson Correlation Test $)$, B. Correlation between expression of placental endoglin and fetal body weight $(r=-0.694 ; p=0.002$, Pearson Correlation Test).

[14] and also by inflammation that occur in the intervillous space of the placenta [15]. Inflammation of the placenta will cause damage to the microvilli that will result in necrosis [16]. Damage to the placenta stimulates proliferation of cytotrophoblast that will lead to thickening of the cytotrophoblast membrane [17]. Transfer of nutrients and oxygen from maternal to fetal will deteriorate due to the mechanical block and inflammatory cells [18].

\section{Placental TGF- $\beta$ did not indicate any significant differ- ences but correlate with fetal body weight}

The level of TGF- $\beta$ in malaria-infected group was higher than non-infected group but did not show any significant difference. These results are similar to the previous research conducted by Lyall et. al. [19], that showed the levels of placental TGF- $\beta 1$ in healthy pregnancy, pre-eclampsia and in pregnant women with fetal growth restriction complication without hypertension, achieved peak level at first trimester, while at third trimester, the levels of TGF- $\beta 1$ did not show any significant differences among the groups. Low levels of TGF- $\beta 1$ is associated with the completion of trophoblast cell invasion into the uterus and the end of placenta growth [19]. According to this condition, the results of TGF- $\beta 1$ level in the case of malaria placental tissue has a similar profile to normal pregnancy, there is no significant difference, especially in the third trimester.

On the other hand, there is another opposite result that Amu et.al [20] has conducted research to compare the expression of placental TGF- $\beta$ in cases of IntraUterine Growth Restriction (IUGR) and non-IUGR. In the IUGR group, there was a significant increase in mRNA expression of placental TGF- $\beta$ compared to non-IUGR group. TGF- $\beta$ also controls trophoblast growth and has constant high level during pregnancy and IUGR conditions [21]. In this study, although there was no significant difference of placental TGF- $\beta$ between the malaria-infected group and non-infected group, the level of placental TGF- $\beta$ in both groups had significant negative correlation with low fetal birth weight. This occurrence may be caused by TGF- $\beta 1$ that exerts bi-functional effects. Pepper, et.al [22], showed in vitro; it can both stimulate and inhibit the proliferation of endothelial cells. In addition, small doses of TGF- $\beta$ stimulate endothelial proliferation, while high doses of TGF- $\beta$ inhibit it [22]. This result also can be caused by the number of samples used that might be too small. Another possibility might become from the role of Interleukin-10 (IL-10) during malaria infection. The IL-10 cytokine has a significant role as an immune regulator of the infections caused by Plasmodium [23]. High levels of IL-10 are associated with inhibition of the proinflammatory response [24]. TGF$\beta$ might be not as central immune regulator in malaria infection.

\section{Placental endoglin was increased in malaria infection}

Placental endoglin expression in the malaria-infected group was higher than the non-infected group. In placental tissue, staining results showed that trophoblast cells in the malaria-infected group showed greater expression of endoglin compared to those of the non-infected group and significantly different. The increasing level of endoglin expression in the placental 
tissue signifies that the tissue is undergoing angiogenesis [25] and also can be caused by the accumulation of infected erythrocytes, monocytes and fibrin deposition in the intervillous space [26]. This condition causes decrease of placental blood flow and tissue perfusion [27].

Hypoxia is a potent stimulus to induce angiogenic factors and induce the expression of endoglin. In vitro study showed that there was an increasing level of mRNA of endoglin after one-hour exposure to hypoxia, and increasing endoglin protein level reached a maximum at 16 hours after exposure to hypoxia [28]. In vivo study revealed that hypoxia was induced by middle cerebral artery occlusion in rat's model caused increasing endoglin in the endothelium of blood vessels in the ischemic brain areas [29]. Based on some reasons above, the possibility of increased expression of endoglin in placental malaria is a compensatory mechanism of the placenta to increase the blood supply to the fetus in case of hypoxia.

\section{CONCLUSIONS}

Endoglin expression and the level of TGF- $\beta$ increase in the placental tissue of malaria pregnant mice although the level of TGF- $\beta$ did not indicate significant difference, yet interestingly endoglin expression and TGF- $\beta$ level have moderate correlation with low fetal weight.

\section{ACKNOWLEDGMENT}

This research was funded by Faculty of Medicine, University of Brawijaya. We thank to Wahyuda Ngatiril Lady, S.Si, Heni Tri Wahyuni, Amd, Bunga Prihadina, S.Si and Surya Kurnia Hayati, S.Si. for their excellent assistance.

\section{REFERENCES}

1. Schantz-Dunn J, Nour NM (2009) Malaria and Pregnancy: A Global Health Perspective. Rev. Obstet Gynecol. 2(3): 186-192.

2. WHO (2012) World Malaria Report. WHO Library Cataloguing-in-Publication Data. Switzerland. p.1. Report No: ISBN 9789241564533.

3. Ndam NT, Deloron P (2007) Molecular aspects of Plasmodium falciparum infection during pregnancy. J Biomed Biotechnol. 2007: 43785.

4. López-Novoa JM (2007) Soluble endoglin is an accurate predictor and a pathogenic molecule in pre-eclampsia. Nephrol Dial Transplant. 22(3): 712-714.

5. Fonsatti E, Maio M (2004) Highlights on endoglin (CD105): from basic findings towards clinical applications in human cancer. J Transl Med. 2: 18.

6. Guerrero-Esteo M, Sanchez-Elsner T, Letamendia A, Bernabeu C (2002) Extracellular and cytoplasmic domains of endoglin interact with the transforming growth factorbeta receptors I and II. J Biol Chem. 277: 29197-29209.

7. Venkatesha S, Toporsian M, Lam C, Hanai J, Mammoto T, Kim YM, Bdolah Y, Lim KH, Yuan HT, Libermann TA, Stillman IE, Roberts D, D'Amore PA, Epstein FH, Sellke FW, Romero R, Sukhatme VP, Letarte M, Karumanchi SA (2006) Soluble endoglin contributes to the pathogenesis of preeclampsia. Nat Med. 12(6): 642-649.

8. Silver KL, Conroy AL, Leke RGF, Leke RJI, Gwanmesia P, Molyneux ME, Wallace DT, Rogerson SJ, Kain KC (2011) Circulating soluble endoglin levels in pregnant women in Cameroon and Malawi-associations with placental malaria and fetal growth restriction. PLoS ONE. 6(9): e24985.

9. Sardjono TW (2005) The effect of Toxoplasma infection pregnancy outcome through interferon-gama (IFN- $\gamma$ ), caspase 3 activation and apoptosis of placenta cells. Doctoral's Dissertation. University of Airlangga. Surabaya.

10. Qin LHJ, Hanes RN, Pluzarev O, Hong J, Crews FT (2008) Increased systemic and brain cytokine production and neuroinflammation by endotoxin following ethanol treatment. Journal of Neuroinflammation. 5: 10.

11. Wang LQ, Zhoub HJ, Pana CF, Zhu SM, Xu LM (2011) Expression of IL- $1 \beta$, IL- 6 and TNF- $\alpha$ in rats with thioacetamide-induced acute liver failure and encephalopathy: correlation with brain edema. Asian Biomedicine. 5: 205215.

12. Mardhiyyah K, Norahmawati E, Fitri LE, Sardjono TW (2011) Fetal low birth weight might be caused by reducing of angiogenesis and increasing of apoptosis of trophoblast cell on placenta of Plasmodium berghei pregnant mice. Master's Thesis. The University of Brawijaya. Malang.

13. Sasmito SD, Fitri LE, Norahmawati E (2011) The effect of peanut hull extract (Arachis hypogea L.) toward low birth weight and the number of leukocytes in mice placenta infected by Plasmodium berghei. Final Project. The University of Brawijaya. Malang.

14. Abrams ET, Brown H, Chensue SW, Turner GDH, Tadesse E, Lema VM, Molyneux ME, Rachfor R, Meshnick SR, Rogerson SJ (2003) Host response to malaria during pregnancy: placental monocyte recruitment is associated pregnancy with elevated- $\beta$ chemokine expression. Journal of immunology. 170: 2759-2764.

15. Rogerson SJ, Pollina E, Getachew A, Tadesse E, Lema VM, Molyneux ME (2003) Placental monocyte infiltrates in response to Plasmodium falciparum infection and their association with adverse pregnancy outcomes. Am J Trop Med Hyg. 68(1): 115-9. 
16. Brabin BJ, Romagosa C, Abdelgalil S, Menendez C, Verhoeff FH, McGready R, Fletcher KA, Owens S, D’Alessandro U, Nosten F, Fischer PR, Ordi J (2004) The sick placenta-the role of malaria. Placenta. 25(5): 359-378

17. Mens PF, Bojtor EC, and Schallig HDFH (2010) Molecular interactions in the placenta during malaria infection. European Journal of Obstetrics Gynecology and Reproductive Biology. 152(2): 126-132.

18. Ismail MR, Ordi J, Menendez C, Ventura PJ, Aponte JJ, Kahigwa E, Hirt R, Cardesa A, Alonso PL (2000) Placental pathology in malaria: a Histological, immunohistochemical, and quantitative study. Hum Pathol. 31(1): 8593.

19. Lyall F, Simpson H, Bulmer JN, Barber J, Robson SC (2001) Transforming growth factor- $\beta$ expression in human placenta and placental bed in third-trimester normal pregnancy, preeclampsia, and fetal growth restriction. Am J Pathol. 159(5): 1827-1838.

20. Amu S, Hahn-zoric M, Malik A, Ashraf R, Zaman S, Kjellmer I, Hagberg H, Padyukov L, Hanson L (2006) Cytokines in the placenta of Pakistani newborns with and without intrauterine growth retardation. Pediatr Res. 59(2): 254-258.

21. Hernandez-Valencia M, Zarate A, Ochoa R, Fonseca ME, Amato D, De Jesus Ortiz M (2001) Insulin-like Growth Factor I, Epidermal Growth Factor and Transforming Growth Factor Beta expression and their association with intrauterine fetal growth retardation, such as development during human pregnancy. Diabetes Obes Metab. 3(6): 457-462.
22. Pepper MS, Vassalli JD, Orci L, Montesano R (1993) Biphasic effect of transforming growth factor- $\beta 1$ on in vitro angiogenesis. Exp Cell Res. 204: 356-363.

23. Couper KN, Blount DG, Riley EM (2008) IL-10: The master regulator of immunity to infection. J Immunol. 180: 5771-5777.

24. Couper KN, Blount DG, Wilson MS, Hafalla JC, Belkaid Y (2008) IL-10 from CD4+ CD252 Foxp3 CD127 adaptive regulatory $\mathrm{t}$ cells modulates parasite clearance and pathology during malaria infection. PLoS Pathog. 4(2): e1000004.

25. Fonsatti E, Maio M (2004) Highlights on endoglin (CD105): from basic findings towards clinical applications in human cancer. J Transl Med. 2: 18.

26. Imamura $\mathrm{T}$, Sugiyama $\mathrm{T}$, Cuevas LE, Makunde R, Nakamura $S$ (2002) Expression of tissue factor, the clotting initiator, on macrophages In Plasmodium falciparum-infected placentas. J Infect Dis. 186(3): 436-40.

27. Rogerson SJ, Hviid L, Duffy PE, Leke RF, Taylor DW (2007) Malaria In Pregnancy: Pathogenesis and Immunity. Lancet Infect Dis. 7(2): 105-17.

28. Li C, Issa R, Kumar P, Hampson IN, Lopez-Novoa JM, Bernabeu C, Kumar S (2003) CD105 Prevents Apoptosis In Hypoxic Endothelial Cells. J Cell Sci. 116: 2677-2685.

29. Zhu Y, Sun Y, Xie L, Jin K, Sheibani N, Greenberg DA (2003) Hypoxic induction of endoglin via a mitogen-activated protein kinases in mouse brain microvascular endothelial cells. Stroke. 34(10): 2483-8. 